\title{
Molecular characterization of nearshore baitfish populations in Bermuda to inform management
}

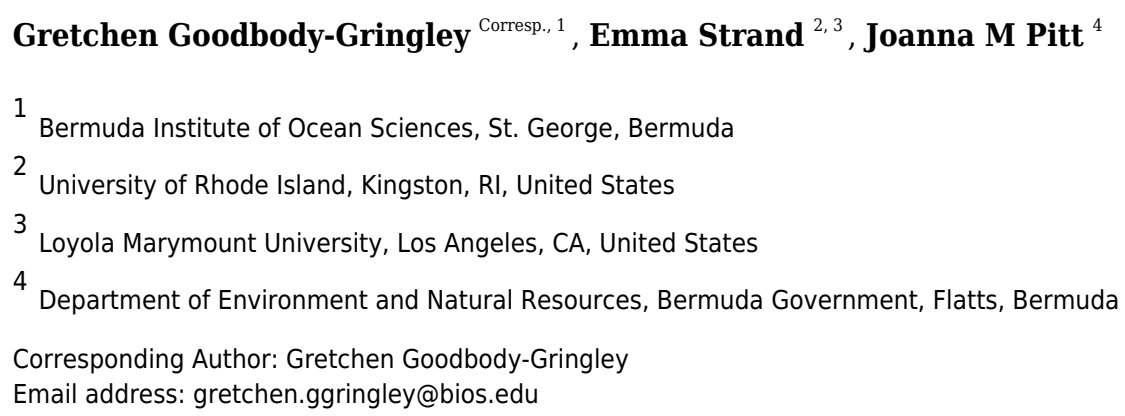

Small-bodied marine fishes play an important role in the food web, feeding both larger fishes and seabirds. Often referred to as baitfishes, they concentrate seasonally in coastal areas in large, often heterospecific assemblages that are targeted by both commercial and recreational fishers. Given apparent declines in at least some of Bermuda's baitfish species over the past 40 years, it is useful to determine the species composition of baitfish assemblages, and how it varies among sites, in order to inform management. Using genetic barcoding of the Cytochrome c oxidase 1 gene (COI), we confirm species identity, assess intraspecific genetic diversity locally, and determine rates of broader genetic connectivity for baitfish assemblages in Bermuda. Species analyzed included Hypoatherina harringtonensis, Anchoa choerostoma, Jenkinsia lamprotaenia, Harengula humeralis, Opisthonema oglinum and Sardinella aurita. Species identification based on molecular barcoding revealed some misidentification of individuals based solely on gross morphological characteristics, with an error rate of $11 \%$, validating the usefulness of this approach. Interestingly, sequence results for the endemic Bermuda anchovy, $A$. choerostoma, were within $1 \%$ similarity to the more broadly distributed big-eye anchovy, A. lamprotaenia, and thus additional analyses are warranted to evaluate the genetic basis for endemism. Estimates of genetic diversity within and among baitfish assemblages in Bermuda were high, indicating high rates of local connectivity among sites for all species. As such, management should consider Bermuda's baitfish species as single, highly mixed populations. However, with the exception of $H$. humeralis and the endemic $A$. choerostoma, significant genetic differentiation and population structure were found when comparing Bermuda's baitfish populations with those from other regions, suggesting limited gene flow between other regions and Bermuda for these species. Limited regional connectivity has implications for management, as strong genetic divergence suggests that 
populations in Bermuda are predominantly self-seeding and thus not likely to be replenished from distant populations. These results therefore support precautionary management of baitfish species in Bermuda. 
1 Molecular characterization of nearshore baitfish populations in Bermuda to inform

2 management

3

4 Gretchen Goodbody-Gringley ${ }^{1 *}$, Emma Strand ${ }^{2,3,}$ Joanna M. Pitt ${ }^{4}$

5

$6 \quad{ }^{1}$ Bermuda Institute of Ocean Sciences, St. George, Bermuda

$7 \quad$ 2University of Rhode Island, Kingston, RI, United States

$8{ }^{3}$ Loyola Marymount University, Los Angeles, CA, United States

$9{ }^{4}$ Department of Environment and Natural Resources, Bermuda Government, Flatts, Bermuda 10

$11 *$ Corresponding author:

12 Gretchen Goodbody-Gringley

1317 Biological Lane, St. Georges, Bermuda GE01

14 Email address: Gretchen.ggringley@,bios.edu

15 


\section{Abstract}

Small-bodied marine fishes play an important role in the food web, feeding both larger

fishes and seabirds. Often referred to as baitfishes, they concentrate seasonally in coastal areas in large, often heterospecific assemblages that are targeted by both commercial and recreational fishers. Given apparent declines in at least some of Bermuda's baitfish species over the past 40 years, it is useful to determine the species composition of baitfish assemblages, and how it varies among sites, in order to inform management. Using genetic barcoding of the Cytochrome $\mathrm{c}$ oxidase 1 gene (COI), we confirm species identity, assess intraspecific genetic diversity locally, and determine rates of broader genetic connectivity for baitfish assemblages in Bermuda. Species analyzed included Hypoatherina harringtonensis, Anchoa choerostoma, Jenkinsia lamprotaenia, Harengula humeralis, Opisthonema oglinum and Sardinella aurita. Species identification based on molecular barcoding revealed some misidentification of individuals based solely on gross morphological characteristics, with an error rate of $11 \%$, validating the usefulness of this approach. Interestingly, sequence results for the endemic Bermuda anchovy, A. choerostoma, were within $1 \%$ similarity to the more broadly distributed big-eye anchovy, A. lamprotaenia, and thus additional analyses are warranted to evaluate the genetic basis for endemism. Estimates of genetic diversity within and among baitfish assemblages in Bermuda were high, indicating high rates of local connectivity among sites for all species. As such, management should consider

34 Bermuda's baitfish species as single, highly mixed populations. However, with the exception of H. humeralis and the endemic A. choerostoma, significant genetic differentiation and population structure were found when comparing Bermuda's baitfish populations with those from other regions, suggesting limited gene flow between other regions and Bermuda for these species. Limited regional connectivity has implications for management, as strong genetic divergence 
39 suggests that populations in Bermuda are predominantly self-seeding and thus not likely to be

40 replenished from distant populations. These results therefore support precautionary management

41 of baitfish species in Bermuda.

42

43 Introduction

44 Small-bodied, shoaling marine fishes are a critical part of the food chain, connecting

45 plankton at low trophic levels to higher trophic level organisms such as seabirds and piscivorous

46 fishes (Smith et al., 2011; Pikitch et al., 2014). These species form large aggregations in coastal

47 areas, and here they are targeted by both commercial and recreational fishers (Smith-Vaniz,

48 Collette \& Luckhurst, 1999; Smith et al., 2011). Commonly referred to as 'forage fish' or

49 'baitfish', their combined ecological and fisheries importance makes these species a priority for

50 management (Smith et al., 2011; Pikitch et al., 2014).

51 In Bermuda, large, heterospecific baitfish aggregations typically include several

52 morphologically similar species from the families Clupeidae, Engraulidae, Atherinidae, and

53 Hemiramphidae (Parrish, 1989; Smith-Vaniz, Collette \& Luckhurst, 1999). Species frequently

54 targeted by fishermen include the Reef silverside, Hypoatherina harringtonensis (G.B. Goode,

55 1877) [Family Atherinidae], the endemic Bermuda anchovy, Anchoa choerostoma (G.B. Goode,

56 1874) [F. Engraulidae], and the Dwarf herring, Jenkinsia lamprotaenia (P.H. Gosse, 1851) [F.

57 Dussumieriidae], as well as the larger and morphologically similar Redear herring, Harengula

58 humeralis (G. Cuvier, 1829), Round sardinella, Sardinella aurita (A. Valenciennes, 1847), and

59 Threadfin herring, Opisthonema oglinum (C.A. Lesueur, 1818), all [F. Clupeidae] (Smith-Vaniz,

60 Collette \& Luckhurst, 1999; Lavoué, Konstantinidis \& Chen, 2014). 
62 fish, which are then used secondarily as either line bait or chum in further fishing activities, or

63

64 65 sold to recreational fishers. Recreational fishers may use a cast net only to catch bait for personal use (Bermuda Fisheries Regulations 2010). Prior to the banning of fish traps in 1990, these small, oily fishes were also placed in mesh bags that were added to traps in order to draw larger fishes to them from greater distances (Butler et al., 1993; Smith-Vaniz, Collette \& Luckhurst, 1999). The annual harvest of baitfishes in Bermuda peaked at $105,072 \mathrm{~kg}$ in 1988 , corresponding with the peak of local trap fishing activity, and fell to a low of 26,842 kg in 1995 (Butler et al., 1993; Smith-Vaniz, Collette \& Luckhurst, 1999). Long-term landings statistics show that, after a decade of adjustment, total reported commercial catches of baitfish species have remained largely stable in the range of 30,000 - 40,000 kg per annum between 1999 and 2017 (Bermuda Government Department of Environment and Natural Resources, pers. comm., www.environment.bm). The Dwarf herring and Bermuda anchovy, which, along with the Reef silverside are collectively called 'fry', make up the bulk of the baitfish harvest (Smith-Vaniz, Collette \& Luckhurst, 1999). However, anecdotal evidence from fishers, together with landings records for the larger baitfish species, suggests that local populations of at least some species have declined over the past 40 years.

For species targeted by fishing, overexploitation can lead to population declines (Ecoutin et al., 2010; Last et al., 2010; Stagličić et al., 2011). Other anthropogenic impacts in coastal areas, such as pollution and habitat degradation (Kennish, 2002; Hewitt et al., 2008; Johnston \& Roberts, 2009), can also alter fish distribution patterns, decreasing richness and abundance across various spatial and temporal scales (Sax \& Gaines, 2003; Johnston \& Roberts, 2009). Apparent declines in the abundance of baitfishes in Bermuda may therefore reflect natural 
84 fluctuations in the abundance and distribution of these species, or may be indicative of

85 overfishing or other anthropogenic impacts. However, a significant change in fishing practices,

86 such as the banning of fish traps, may also affect the ways in which a related resource, such as

87 bait, is harvested and used, which may in turn affect how that resource is perceived and

88 monitored by fishers.

89 At present, regulation of baitfishing in Bermuda under the Fisheries Act, 1972, and the

90 Fisheries Regulations, 2010, includes both gear and spatial restrictions. In particular, there are

91 four inshore bays (Somerset Long Bay, Shelly Bay, Whalebone Bay, and Coot Pond), within

92 which the use of fishing nets and the removal of baitfishes is completely prohibited (Bermuda

93 Fisheries Act, 1972, Section 8i), but these bays are not evenly distributed around the island (Fig.

94 1). Further, given the similarities in species morphologies, visual identification of baitfish

95 species in the field can be difficult, and a higher diversity may exist within baitfish schools than

96 is currently perceived. Thus, increased understanding of how assemblage composition varies

97 across locations, along with the extent of local movements and genetic mixing, is required to

98 inform management.

99 Lastly, if Bermuda's baitfish populations are indeed experiencing declines, a greater

100 understanding of regional genetic connectivity could indicate whether or not larval supply from

101 other populations might assist with their recovery (see Cowen \& Sponaugle, 2009). Bermuda's

102 isolated, mid-Atlantic location (Fig. 1, inset) reduces the likelihood of regular supply of larvae

103 from external sources (Schultz \& Cowen, 1994), and there is evidence indicating that at least

104 some local fish populations are self-seeding (see Locke et al., 2013). However, despite this

105 isolation, Bermuda was the first location outside of the eastern coast of the United States where

106 invasive lionfish were detected (Whitfield et al., 2002), indicating that larval transport and / or 
107 post-larval rafting in association with floating material across this distance is not only possible

108 but occurs at a rate that enabled successful establishment of an invasive species (Locke et al.,

109 2013). Further, Bermuda has low rates of endemism (Smith-Vaniz, Collette \& Luckhurst, 1999),

110 suggesting at least some genetic connectivity with other regions (see Locke et al., 2013).

111 Using genetic barcoding of the Cytochrome c oxidase 1 gene (COI), we aim to confirm

112 species identity, assess intraspecific genetic diversity, and determine rates of local and regional

113 genetic connectivity of Bermuda's baitfish populations. Barcoding has proven useful for species

114 verification in families with a high degree of morphological similarity, and has been able to

115 identify new species by integrative taxonomic analysis (Ward, Hanner \& Hebert, 2009).

116 Furthermore, population genetic analyses can suggest points of origin in mixed populations and

117 provide insights to breeding structures (Allendorf \& Utter, 1979). Thus, results of this study will

118 provide insights into population stability and can be used to inform future management

119 strategies.

120

121 Methods

122 Samples were collected from 10 locations around the islands of Bermuda: the Bermuda

123 Aquarium Museum and Zoo dock in Flatts (BAMZ), Bailey's Bay, Coney Island, Whalebone

124 Bay, Turtle Bay, South Bay, East Whale Bay, West Whale Bay, Frank's Bay, and Deep Bay,

125 between July and August 2017 (Fig. 1 - clockwise from center). All samples were collected with

126 permission of the Bermuda Government Department of Environment and Natural Resources

127 under special permit SP170303. A total of 111 individuals were collected and visually identified

128 in the field based on previously described gross morphological characteristics (Smith-Vaniz,

129 Collette \& Luckhurst, 1999). Based on these initial examinations, five species were identified: 
130 131

132

133

134

135 136

137

139

140

141

142

143

144

145

146

147

148

149

150

151

152

Hypoatherina harringtonensis (Reef silverside), Anchoa choerostoma (Bermuda anchovy),

Jenkinsia lamprotaenia (Dwarf herring), Harengula humeralis (Redear herring) and Sardinella

aurita (Round sardinella). Representative samples of each species from each location were preserved in 95\% ethanol for subsequent genetic analyses.

Genomic DNA was extracted from muscle tissue of samples using a Qiagen DNA Blood and Tissue extraction kit following the manufacturer's protocols, resulting in a final volume of $200 \mu \mathrm{l}$. The cytochrome c oxidase (COI) gene was amplified from extracted DNA using a primer cocktail developed for fish barcoding as described by Ivanova et al. (2007) (COI-3: C_FishF1t1C_FishR1t1). All PCRs had a total volume of $12.5 \mu$ land included: $6.25 \mu 1$ of 5\% DMSO, 2.00 $\mu \mathrm{l}$ of $\mathrm{H}_{2} \mathrm{O}, 1.25 \mu \mathrm{l}$ of $10 x$ Buffer [10mM KCl, 10mM $\left(\mathrm{NH}_{4}\right) \mathrm{SO}_{4}, 20 \mathrm{mM}$ Tris- $\mathrm{HCl}(\mathrm{pH} 8.8)$, $2 \mathrm{mM} \mathrm{MgSO}_{4}, 0.1 \%$ Triton X-100], $0.625 \mu \mathrm{L} \mathrm{MgCl}_{2}(50 \mathrm{mM}), 0.125 \mu$ l of each primer cocktail, $0.0625 \mu \mathrm{l}$ of DNTP (10 mM), $0.0625 \mu \mathrm{l}$ of Taq Polymerase (Invitrogen), and $2 \mu \mathrm{l}$ of DNA template. PCR was optimized at the following: $95^{\circ} \mathrm{C}$ for 2 minutes, 35 cycles of $94{ }^{\circ} \mathrm{C}$ for 30 seconds, $52^{\circ} \mathrm{C}$ for 30 seconds, $72^{\circ} \mathrm{C}$ for 1 minute, with a final extension at $72^{\circ} \mathrm{C}$ for 10 minutes. PCR products were visualized using a 1.2\% agarose gel, with concentration and purity measured using a spectrophotometer. Products were bi-directionally sequenced with universal M13 primers using Sanger Sequencing services provided by Gene Codes Corporation. Resulting sequences were manually edited and aligned using Sequencher ${ }^{\circledR}$ 5.4.6 (Gene Codes Corporation, Ann Arbor, MI, USA) and compared to known sequences in NCBI Blast and GenBank. Accession numbers are listed in Appendix 1, all sequences are available on GenBank (www.ncbi.nlm.nih.gov/Genbank). Available sequences of the COI gene for conspecifics from locations outside Bermuda were downloaded from GenBank and used for regional comparisons of genetic structure and connectivity (Valdez-Moreno et al., 2010; Lavoué, Konstantinidis \& 
153 Chen, 2014). Sequences from Anchoa lamprotaenia [Hildebrand, 1943] from Florida (Weigt et

154 al., 2012; Lavoué, Konstantinidis \& Chen, 2014) were used for comparisons with $A$.

155 choerostoma, as no COI sequences were available for $A$. choerostoma.

156 Sequences for all species, including those obtained from GenBank, were aligned using

157 MUSCLE (Edgar, 2004). Single gene phylogenetic analysis of the genera examined was

158 conducted using the Maximum Likelihood method based on the Tamura-Nei model (Tamura \&

159 Nei, 1993). Initial trees for the heuristic search were obtained automatically by applying

160 Neighbor-Join and BioNJ algorithms to a matrix of pairwise distances estimated using the

161 Maximum Composite Likelihood (MCL) approach, and then selecting the topology with superior

$162 \log$ likelihood value. The analysis involved 154 nucleotide sequences, with a total of 718

163 positions in the final dataset. Evolutionary analyses were conducted in MEGA X (Kumar et al., 164 2018).

165 Diversity was assessed within and among locations in Bermuda using standard diversity 166 indices, including number of haplotypes $(\mathrm{Nh})$, number of polymorphic sites $(\mathrm{Np})$, haplotypic 167 diversity (h) (Nei, 1987), nucleotide diversity (pn) (Tajima, 1983; Nei, 1987), and mean number 168 of pairwise differences $(p d)$ between haplotypes (Tajima, 1983) calculated for each species using 169 DnaSP v.5 (Librado \& Rozas, 2009). Population (location) pairwise $F_{\mathrm{ST}}$ (Hudson, Slatkin \& 170 Maddison, 1992) values, whose significances were assessed through 10,000 permutation tests, 171 were used to calculate differentiation between locations within Bermuda, as well between

172 Bermuda and other regional locations, using ARLEQUIN version 3.5.2 (Excoffier \& Lischer,

173 2010). Unweighted analysis of molecular variance (AMOVA; (Excoffier, Smouse \& Quattro,

174 1992) was also performed to test hierarchical models of genetic variance using pairwise

175 differences among haplotypes as a measure of divergence within and among locations in 
176 Bermuda as well as within and among regional locations using ARLEQUIN version 3.5.2

177 (Excoffier \& Lischer, 2010).

178

179 Results

180 A total of 92 individual fish were successfully sequenced (see Appendix 1). Alignments

181 for each species were trivial and required no insertion / deletion events. Sequence identification

182 of 81 individuals confirmed initial identification, while sequence identification did not match the

183 initial field identification for 10 individuals, indicating an error rate of $11 \%$ for identification

184 based on gross morphology.

185 All three samples from Deep Bay, initially identified as Sardinella aurita, were

186 molecularly identified as Opisthonema oglinum. Five of the seven samples from the BAMZ

187 location that were initially identified as $S$. aurita were also molecularly identified as O. oglinum.

188 One sample from Frank's Bay and one sample from Coney Island were identified as

189 Hypoatherina harringtonensis, but the resulting sequences matched that of Jenkinsia

190 lamprotaenia. COI sequences of individuals morphologically identified as the endemic Bermuda

191 anchovy, Anchoa choerostoma, had a 99\% identity match (93\% query coverage) to the

192 widespread Atlantic species $A$. lamprotaenia. However, no COI sequences were available for $A$.

193 choerostoma on public databases for comparison.

194 The single gene tree constructed based on maximum likelihood to infer phylogenetic

195 relationships (Fig. 2) indicated that species from the genera Harengula, Opisthonema, and

196 Sardinella are more closely related to each other than to the other species examined, while

197 species from the genera Jenkinsia and Anchoa are more closely related to each other than to the 
198 other species. The genus Hypoatherina, in the order Atheriniformes, was the most evolutionarily 199 distant from the other genera.

200 Haplotype diversity was similar among species based on overlapping standard errors

201 (Table 1). Nucleotide diversity was similar for A. choerostoma and H. harringtonensis, and for

202 H. humeralis, J. lamprotaenia, and O. oglinum, but was higher for the first two species than for

203 the latter three. The mean number of pairwise differences was highest for A. choerostoma at

2043.163 , decreasing to 0.934 for J. lamprotaenia, 0.800 for $H$. humeralis, 0.780 for $H$.

205 harringtonensis, and 0.429 for O. oglinum. Diversity of A. choerostoma within a given bay was

206 higher at East Whale Bay than at West Whale Bay and BAMZ (Table 1). For H. harringtonensis,

207 within-location diversity was higher at BAMZ and Whalebone Bay than at Frank's Bay and

208 Bailey's Bay. Diversity was similar among locations for H. humeralis at BAMZ and Coney

209 Island, and among all sampled locations for J. lamprotaenia. Likewise, diversity measures did

210 not differ among locations for O. oglinum from Deep Bay and BAMZ. While measures of

211 diversity were high for $S$. aurita, the low sample size $(\mathrm{n}=2)$ and lack of replicate sites precludes

212 their inclusion in diversity comparisons (Table 1).

213 Pairwise $F_{\mathrm{ST}}$ comparisons between locations within Bermuda were insignificant $(\alpha=0.05)$

214 for all species examined, indicating no evidence of genetic structure and high levels of genetic

215 connectivity within and among locations (Table 2). An analysis of molecular variance used to

216 test for hierarchical population structure also indicated no significant genetic structure exists

217 among locations in Bermuda for any of the species analyzed, where the majority of variation for

218 all species was found within locations rather than among them (Table 3).

219 For all species except $H$. humeralis, pairwise $F_{\mathrm{ST}}$ comparisons were significant $(\alpha=0.05)$

220 between populations from Bermuda and those from other regions, indicating strong evidence of 
221 genetic structure and limited genetic connectivity across regions (Table 4). An analysis of

222 molecular variance, used to test for hierarchical population structure, also showed significant

223 genetic structure among regions for all species analyzed with the exception of $H$. humeralis, such

224 that the majority of variation was found among regions rather than within them (Table 5).

225

226 Discussion

227 Based on the COI sequences obtained from baitfish samples in this study, a higher

228 diversity of species was present within the assemblages than was initially recorded based solely

229 on morphological identification in the field at the time of sampling, with $11 \%$ of individuals

230 being misidentified. Genetic sequencing revealed the misidentification of several small

231 individuals of Opisthonema oglinum that had yet to develop their distinctive threadfin and were

232 thus misidentified as Sardinella aurita, and of two small Jenkinsia lamprotaenia that had been

233 schooling with Hypoatherina harringtonensis. As a result, the total number of species analyzed

234 increased from five to six, and included Anchoa choerostoma, H. harringtonensis, H. humeralis,

235 J. lamprotaenia, O. oglinum, and S. aurita. These results highlight the value of incorporating

236 molecular identification into assessments of species assemblages for morphologically similar

237 species, as diversity may be underestimated when based only on gross morphology (Zemlak et

238 al., 2009; Hubert et al., 2012).

239 The relationship among the limited sampling of six genera of baitfishes examined in this

240 study was analyzed using a single gene tree based on a Maximum Likelihood phylogenetic

241 approach and broadly follows established relationships (e.g. in Lavoué, Konstantinidis \& Chen,

242 2014) in that the genera within the Family Clupeidae (Harengula, Opisthonema, and Sardinella)

243 were found to be more closely related to each other than to the other genera examined (Fig. 2). 
244 However, while our analysis found Jenkinsia (Family Dussumieriidae) and Anchoa (Family

245 Engraulidae) to be more closely related to each other than to the species in the Clupeidae, recent

246 molecular phylogenies using multiple markers have inferred conflicting sister relationships

247 between the Dussumieriidae, the Engraulidae and the rest of the Clupeoidei (see Lavoue et al.,

2482017 and Egan et al., 2018). Deciphering these relationships is beyond the scope of the present

249 single gene analysis of five species but, as COI sequences become available for more species,

250 these data may contribute to future analyses to further elucidate the complex evolutionary history

251 of this group of fishes. All of the aforementioned genera belong to the Order Clupeiformes,

252 while Hypoatherina belongs to the Order Atheriniformes. Accordingly, H. harringtonensis was

253 found to be the most evolutionarily distant from the other genera examined.

254 Interestingly, the COI sequence results for the endemic Bermuda Anchovy, $A$.

255 choerostoma, were within $1 \%$ similarity to the more broadly distributed Big-eye anchovy, $A$.

256 lamprotaenia. A. choerostoma was described by Goode in 1874 based on morphological

257 variations from congeneric species. Morphologically, it is most similar to A. lamprotaenia, $A$.

258 januaria, A. cubana and A. parva (Smith-Vaniz, Collette \& Luckhurst, 1999; Nizinski \&

259 Munroe, 2002). However, molecular phylogenies have found it most closely related to $A$.

260 mitchilli using the ITS1 region (Johnson 2003 in Smith-Vaniz \& Collette, 2013), and to $A$.

261 hepsetus using a combination of the genes 12s, 16s, RAG1 and RAG2 (Li \& Ortí, 2007), but

262 these studies did not include $A$. lamprotaenia. Of these species, $A$. hepsetus is readily

263 distinguished from the others by its longer maxilla (Nizinski \& Munroe, 2002). A. choerostoma

264 is distinguished from A. mitchilli by the relative positions of the dorsal fin and anal fin (such that

265 the anal fin in A. choerostoma is posterior to the dorsal, whereas the origins of these fins are

266 vertically aligned in A. mitchilli); from A. lamprotaenia by having a greater number of lower gill 
267 rakers (23-30 as opposed to 17-21); and from the remaining similar congenerics by having a

268 notably smaller axillary scale above the pectoral fin (Smith-Vaniz, Collette \& Luckhurst, 1999;

269 Nizinski \& Munroe, 2002).

270 Cytochrome c oxidase is an enzyme in the respiratory chain that catalyzes the conversion

271 of oxygen to water, a critical survival process. Encoded inside mitochondria, the Cytochrome c

272 oxidase subunit 1 gene (COI) is highly conserved among all respiring organisms and is therefore

273 not subject to selective pressures that induce mutation (Mick, Fox \& Rehling, 2011). It is

274 possible, therefore, that the COI gene may not provide high enough resolution to distinguish

275 between these closely related species within the genus Anchoa. To further evaluate and obtain an

276 accurate assessment of endemism, multiple genes should be incorporated and compared among

277 several congeneric species. Coupled with morphological variation, detailed phylogenetic

278 analyses could provide further insights into the classification of the Bermuda anchovy.

279 Of the locations examined around Bermuda, BAMZ had the highest species diversity, 280 with all six species found at this location (Fig. 1). Conversely, at several locations, only a single

281 species was found. However, this may reflect sampling effort rather than actual diversity, as

282 these sites were sampled less frequently than BAMZ. Yet, BAMZ is also the most centrally

283 located site on the more protected northern shore of Bermuda, and may, therefore, represent an

284 area of species accumulation (Tittensor et al., 2010), at least for inshore species, that results in

285 higher baitfish diversity. Among the species, J. lamprotaenia was the most widely distributed,

286 being found at five of the 10 locations, followed by H. harringtonensis at four of the 10

287 locations. Given the high estimates of connectivity among locations for all six species examined,

288 however, distributions are likely wider than reflected by the somewhat limited sampling effort in 289 this study. 

indicate high degrees of mixing between locations for all six species examined. For these small-

292 bodied species, this mixing likely occurs predominantly during the larval phase (Schultz, 2000;

293 Lavoué, Konstantinidis \& Chen, 2014), but may also occur during later life stages as a result of 294 short- or long-term movements between locations that may be driven by food availability, 295 predator density, reproductive cycles or adverse conditions (Hugie \& Dill, 1994; Olsson et al., 296 2006; Udyawer et al., 2013; Currey et al., 2015). These high rates of local connectivity mean that 297 management should consider Bermuda's baitfish species as single, highly mixed populations. As 298 such, the distribution of bays that are closed to net fishing in order to protect them is of less 299 importance than it might be if subregional genetic differentiation had been detected, and there is 300 no immediate need to close additional bays in central or western parishes, or along the south 301 shore, in order to maintain local genetic diversity.

On a larger scale, most marine species occurring in Bermuda are restricted to the Tropical 303 Northwestern Atlantic biogeographic province (Spalding et al., 2007; Locke et al., 2013), which 304 is largely equivalent to the Caribbean biogeographic province of Kulbicki et al. (2013), and the 305 baitfish species examined here generally follow this distributional pattern. In contrast, S. aurita 306 is found on both sides of the Atlantic Ocean and into the Mediterranean Sea (Aquamaps, 2016). 307 However, range size does not necessarily reflect modern dispersal patterns (Lester et al., 2007) 308 and, for marine fishes, small body size is correlated with lower dispersal capacity and increased 309 rates of endemism (DeMartini and Friedlander 2004; Bradbury et al 2008). This seems likely to 310 apply to baitfish species, with implications for regional connectivity for an isolated island like 311 Bermuda. 
313 populations of baitfishes in Bermuda and those in other regions (Table $4 ; F_{\mathrm{ST}} ; \mathrm{p}<0.05$ ), and

314 significant divergence among regions (Table 5; AMOVA; $<<0.05$ ) for J. lamprotaenia, $H$.

315 harringtonensis, O. oglinum, and S. aurita, as well as between congeneric populations of Anchoa

$316 s p$. among regions. These results suggest that gene flow, and therefore exchange of individuals,

317 is limited between populations of these species in Bermuda and those in other regions.

318 Populations of $H$. humeralis, on the other hand, show no evidence of genetic structure,

319 suggesting broad genetic connectivity exists across the Caribbean / Tropical West Atlantic for

320 this species. Importantly, these results have major implications for management as strong genetic

321 divergence in J. lamprotaenia, H. harringtonensis, O. oglinum, and S. aurita suggests that

322 populations of these species in Bermuda are likely self-seeding and locally maintained. Thus,

323 local declines in baitfish abundances are not likely to be replenished from distant populations.

\section{Conclusion}

Baitfishes depend on shallow inshore areas, which are capable of sustaining great

327 diversity and densities of organisms (Nagelkerken et al., 2001; Ray \& Carleton Ray, 2005;

328 Vasconcelos et al., 2011; Araújo et al., 2017), but are also extensively modified and threatened

329 by human activities such as overfishing, pollution, coastal development and habitat degradation,

330 which may impact fish communities (Kennish, 2002; Sax \& Gaines, 2003; Ribeiro et al., 2008;

331 Johnston \& Roberts, 2009; Ecoutin et al., 2010; Last et al., 2010; Araújo et al., 2017). The

332 limited genetic connectivity of baitfish populations among Western Atlantic regions documented

333 here indicates restricted influx of new individuals to Bermuda and highlights the vulnerability of

334 local populations to natural and anthropogenic perturbations. As such, it is important to monitor 
335 both fish communities and environmental parameters in Bermuda's nearshore habitats (Araújo et

336 al., 2017), and to adapt management measures accordingly, in order to conserve these

337 ecologically and economically important species.

338

339 Acknowledgements

340 We are grateful to Jirani Welch, Chris Flook and Robbie Smith for their assistance with

341 collecting samples.

342 


\section{References}

344 Allendorf FW, Utter FM. 1979. Population Genetics. In: Fish Physiology. 407-454.

345 Aquamaps 2016. Reviewed distribution maps for Sardinella aurita (Round sardinella), with

346 modelled year 2100 native range map based on IPCC A2 emissions scenario. 2016.

$347 \quad$ Available at www.aquamaps.org (accessed March 7, 2019).

348 Araújo FG, Pinto SM, Neves LM, de Azevedo MCC. 2017. Inter-annual changes in fish

349 communities of a tropical bay in southeastern Brazil: What can be inferred from

$350 \quad$ anthropogenic activities? Marine pollution bulletin 114:102-113.

351 Bradbury IR, Laurel B, Snelgrove PVR, Bentzen P, Campana SE. 2008 Global patterns in

352 marine dispersal estimates: the influence of geography, taxonomic category and life history.

353 Proceedings of the royal society B 275:1803-1809.

354 Butler JN, Burnett-Herkes J, Barnes JA, Ward J. 1993. The Bermuda Fisheries a Tragedy of the

355 Commons Averted? Environment: Science and Policy for Sustainable Development 35:6-

356 33. DOI: $10.1080 / 00139157.1993 .9929067$.

357 Cowen RK, Sponaugle S. 2009. Larval dispersal and marine population connectivity. Annual

358 review of marine science 1:443-466.

359 Currey LM, Heupel MR, Simpfendorfer CA, Williams AJ. 2015. Assessing environmental

360 correlates of fish movement on a coral reef. Coral reefs 34:1267-1277.

361 DeMartini EE, Friedlander AM. 2004. Spatial patterns of endemism in shallow-water reef fish

362 populations of the Northwestern Hawaiian Islands. Marine ecology progress series 271:281-

363296.

364 Ecoutin JM, Simier M, Albaret JJ, Laë R, de Morais LT. 2010. Changes over a decade in fish

365 assemblages exposed to both environmental and fishing constraints in the Sine Saloum

366 estuary (Senegal). Estuarine, coastal and shelf science 87:284-292. 
367 Edgar RC. 2004. MUSCLE: a multiple sequence alignment method with reduced time and space $368 \quad$ complexity. BMC bioinformatics 5:113.

369 Egan JP, Bloom DD, Chien-Hsien K, Hammer MP, Tongnunui P, Iglésias SP, Sheaves M, 370 Grudpan C, Simons AM. 2018. Phylogenetic analysis of trophic niche evolution reveals a 371 latitudinal herbivory gradient in Clupeoidei (herrings, anchovies, and allies). Molecular 372 phylogeny and evolution 124:151-161.

373 Excoffier L, Lischer HEL. 2010. Arlequin suite ver 3.5: a new series of programs to perform 374 population genetics analyses under Linux and Windows. Molecular ecology resources $375 \quad 10: 564-567$.

376 Excoffier L, Smouse PE, Quattro JM. 1992. Analysis of molecular variance inferred from metric 377 distances among DNA haplotypes: application to human mitochondrial DNA restriction 378 data. Genetics 131:479-491.

379 Hewitt LM, Kovacs TG, Dubé MG, MacLatchy DL, Martel PH, McMaster ME, Paice MG, 380 Parrott JL, van den Heuvel MR, van der Kraak GJ. 2008. Altered reproduction in fish 381 conditions. Environmental toxicology and chemistry / SETAC 27:682-697.

383 384 385 386 387 388 389

Hubert N, Meyer CP, Bruggemann HJ, Guérin F, Komeno RJL, Espiau B, Causse R, Williams JT, Planes S. 2012. Cryptic diversity in Indo-Pacific coral-reef fishes revealed by DNAbarcoding provides new support to the centre-of-overlap hypothesis. PloS one 7:e28987.

Hudson RR, Slatkin M, Maddison WP. 1992. Estimation of levels of gene flow from DNA sequence data. Genetics 132:583-589.

Hugie DM, Dill LM. 1994. Fish and game: a game theoretic approach to habitat selection by predators and prey. Journal of fish biology 45:151-169. 
390 Ivanova NV, Zemlak TS, Hanner RH, Hebert PDN. 2007. Universal primer cocktails for fish $391 \quad$ DNA barcoding. Molecular ecology notes 7:544-548.

392 Johnston EL, Roberts DA. 2009. Contaminants reduce the richness and evenness of marine 393 communities: A review and meta-analysis. Environmental pollution 157:1745-1752.

394 Kennish MJ. 2002. Environmental threats and environmental future of estuaries. Environmental conservation 29. DOI: 10.1017/s0376892902000061.

396 Kulbicki M, Parravicini V, Bellwood DR, Arias-Gonzàlez E, Chabanet P, Floeter SR, doi:10.1371/journal.pone.0081847.

400 Kumar S, Stecher G, Li M, Knyaz C, Tamura K. 2018. MEGA X: Molecular Evolutionary 401 Genetics Analysis across Computing Platforms. Molecular biology and evolution 35:1547$402 \quad 1549$.

403 Last PR, White WT, Gledhill DC, Hobday AJ, Brown R, Edgar GJ, Pecl G. 2010. Long-term 404 shifts in abundance and distribution of a temperate fish fauna: a response to climate change 405 and fishing practices. Global ecology and biogeography: a journal of macroecology 20:58406 72.

407 Lavoué S, Bertrand JAM, Chen W-J, Ho H-C, Motomura H, Sado T, Miya M. 2017.

408 Phylogenetic position of the rainbow sardine Dussumieria (Dussumieriidae) and its bearing 409 on the early evolution of the Clupeoidei. Gene 623:41-47.

410 Lavoué S, Konstantinidis P, Chen W-J. 2014. Progress in Clupeiform Systematics. In: Biology 411 and Ecology of Sardines and Anchovies. 3-42.

412 Lavoué S, Miya M, Musikasinthorn P, Chen W-J, Nishida M. 2013. Mitogenomic evidence for 
an Indo-West Pacific origin of the Clupeoidei (Teleostei: Clupeiformes). PloS one 8:e56485.

414 Lester SE, Ruttenberg BI, Gaines SD, Kinlan BP. 2007 The relationship between dispersal

415 ability and geographic range size. Ecology letters 10(8):745-758.

416 Librado P, Rozas J. 2009. DnaSP v5: a software for comprehensive analysis of DNA

417 polymorphism data. Bioinformatics 25:1451-1452.

418 Li C, Ortí G. 2007. Molecular phylogeny of Clupeiformes (Actinopterygii) inferred from nuclear

419 and mitochondrial DNA sequences. Molecular phylogenetics and evolution 44:386-398.

420 DOI: $10.1016 /$ j.ympev.2006.10.030.

421 Locke JM, Coates KA, Bilewitch JP, Holland LP, Pitt JM, Smith SR, Trapido-Rosenthal HG.

422 2013. Biogeography, Biodiversity and Connectivity of Bermuda's Coral Reefs. In: Sheppard

423 CRC ed. Coral Reefs of the United Kingdom Overseas Territories. Dordrecht: Springer

$424 \quad$ Netherlands, 153-172.

425 Mick DU, Fox TD, Rehling P. 2011. Inventory control: cytochrome c oxidase assembly regulates

426 mitochondrial translation. Nature reviews. Molecular cell biology 12:14-20.

427 Nagelkerken I, Kleijnen S, Klop T, van den Brand R, de la Morinière EC, van der Velde G.

428 2001. Dependence of Caribbean reef fishes on mangroves and seagrass beds as nursery

429 habitats: a comparison of fish faunas between bays with and without mangroves/seagrass

$430 \quad$ beds. Marine ecology progress series 214:225-235.

431 Nei M. 1987. Molecular Evolutionary Genetics. Columbia University Press.

432 Nizinski MS, Munroe TA. 2002. Order Clupeiformes, Engraulidae. In: Carpenter KE ed. The

433 living marine resources of the Western Central Atlantic. Volume 2: Bony fishes part 1

434 (Acipenseridae to Grammatidae). FAO Species Identification Guide for Fishery Purposes

435 and American Society of Ichthyologists and Herpetologists Special Publication No. 5. 
Rome: FAO, 764-780.

437 Olsson IC, Greenberg LA, Bergman E, Wysujack K. 2006. Environmentally induced migration:

438 the importance of food. Ecology letters 9:645-651.

439 Parrish JK. 1989. Layering with depth in a heterospecific fish aggregation. Environmental $440 \quad$ biology of fishes 26:79-85.

441 Pikitch EK, Rountos KJ, Essington TE, Santora C, Pauly D, Watson R, Sumaila UR, Boersma 442 PD, Boyd IL, Conover DO, Cury P, Heppell SS, Houde ED, Mangel M, Plagányi É, 443 Sainsbury K, Steneck RS, Geers TM, Gownaris N, Munch SB. 2014. The global 444 contribution of forage fish to marine fisheries and ecosystems. Fish and fisheries 15:43-64. 445 Ray GC, Carleton Ray G. 2005. Connectivities of estuarine fishes to the coastal realm. $446 \quad$ Estuarine, coastal and shelf science 64:18-32.

447 Ribeiro J, Monteiro CC, Monteiro P, Bentes L, Coelho R, Gonçalves JMS, Lino PG, Erzini K. 448 2008. Long-term changes in fish communities of the Ria Formosa coastal lagoon (southern 449 Portugal) based on two studies made 20years apart. Estuarine, coastal and shelf science 450 76:57-68.

451 Sax DF, Gaines SD. 2003. Species diversity: from global decreases to local increases. Trends in 452 ecology \& evolution 18:561-566.

453 Schultz E. 2000. Explaining advection: do larval bay anchovy (Anchoa mitchilli) show selective 454 tidal-stream transport? ICES journal of marine science: journal du conseil 57:360-371.

455 Schultz ET, Cowen RK. 1994. Recruitment of coral-reef fishes to Bermuda: local retention or 456 long-distance transport? Marine ecology progress series 109:15-28. DOI:

$457 \quad 10.3354 / \operatorname{meps} 109015$.

458 Smith ADM, Brown CJ, Bulman CM, Fulton EA, Johnson P, Kaplan IC, Lozano-Montes H, 
459

460

461

462

463

464

465

466

467

468

469

470

471

472

473

474

475

476

477

478

479

480

481

Mackinson S, Marzloff M, Shannon LJ, Shin Y-J, Tam J. 2011. Impacts of fishing lowtrophic level species on marine ecosystems. Science 333:1147-1150.

Smith-Vaniz W, Collette BB. 2013. Fishes of Bermuda. Aqua, International journal of ichthyology 19:165-186.

Smith-Vaniz WF, Collette BB, Luckhurst BE. 1999. Fishes of Bermuda: history, zoogeography, annotated checklist, and identification keys.

Spalding MD, Fox HE, Allen GR, Davidson N, Ferdaña ZA, Finlayson M, Halpern BS, Jorge MA, Lombana A, Lourie SA, Martin KD, McManus E, Molnar J, Recchia CA, Robertson J. 2007. Marine Ecoregions of the World: A Bioregionalization of Coastal and Shelf Areas. Bioscience 57:573-583.

Stagličić N, Matić-Skoko S, Pallaoro A, Grgičević R, Kraljević M, Tutman P, Dragičević B, Dulčić J. 2011. Long-term trends in the structure of eastern Adriatic littoral fish assemblages: Consequences for fisheries management. Estuarine, coastal and shelf science 94:263-271.

Tajima F. 1983. Evolutionary relationship of DNA sequences in finite populations. Genetics 105:437-460.

Tamura K, Nei M. 1993. Estimation of the number of nucleotide substitutions in the control region of mitochondrial DNA in humans and chimpanzees. Molecular biology and evolution 10:512-526.

Tittensor DP, Mora C, Jetz W, Lotze HK, Ricard D, Berghe EV, Worm B. 2010. Global patterns and predictors of marine biodiversity across taxa. Nature 466:1098-1101.

Udyawer V, Chin A, Knip DM, Simpfendorfer CA, Heupel MR. 2013. Variable response of coastal sharks to severe tropical storms: environmental cues and changes in space use. 
$482 \quad$ Marine ecology progress series 480:171-183.

483 Valdez-Moreno M, Vásquez-Yeomans L, Elías-Gutiérrez M, Ivanova NV, Hebert PDN. 2010.

484 Using DNA barcodes to connect adults and early life stages of marine fishes from the

485 Yucatan Peninsula, Mexico: potential in fisheries management. Marine and Freshwater

$486 \quad$ Research 61:655.

487 Vasconcelos RP, Reis-Santos P, Costa MJ, Cabral HN. 2011. Connectivity between estuaries and 488 marine environment: Integrating metrics to assess estuarine nursery function. Ecological $489 \quad$ indicators 11:1123-1133.

490 Ward RD, Hanner R, Hebert PDN. 2009. The campaign to DNA barcode all fishes, FISH-BOL. $491 \quad$ Journal of fish biology 74:329-356.

492 Weigt LA, Baldwin CC, Driskell A, Smith DG, Ormos A, Reyier EA. 2012. Using DNA 493 barcoding to assess Caribbean reef fish biodiversity: expanding taxonomic and geographic $494 \quad$ coverage. PloS one 7:e41059.

495 Whitfield PE, Gardner T, Vives SP, Gilligan MR, Ray WRC, Ray GC, Hare JA. 2002.

496 Biological invasion of the Indo-Pacific lionfish Pterois volitans along the Atlantic coast of 497 North America. Marine ecology progress series 235:289-297. DOI: 10.3354/meps235289.

498 Zemlak TS, Ward RD, Connell AD, Holmes BH, Hebert PDN. 2009. DNA barcoding reveals 499 overlooked marine fishes. Molecular ecology resources 9 Suppl s1:237-242. 


\section{Table $\mathbf{1}$ (on next page)}

Diversity Measures.

Standard diversity measures by sampling location for $A$. choerostoma, $H$. harringtonensis, $H$. humeralis, J. lamprotaenia, O. oglinum, and $S$. aurita including sample size ( $n)$, number of usable base pairs (bp), number of haplotypes (Nh), number of polymorphic sites (Np), haplotype diversity $(h)$, nucleotide diversity $(p n)$, and the mean number of pairwise differences $(p d)$. 


\begin{tabular}{llccccccc}
\hline Species & Location & $n$ & $b p$ & $N h$ & $N p$ & $h$ & $p n$ & $p d$ \\
\hline \multirow{2}{*}{ A. choerostoma } & ALL & 20 & 710 & 11 & 16 & $0.763+/-0.103$ & $0.0045+/-0.0010$ & 3.163 \\
& West Whale Bay & 4 & 710 & 2 & 1 & $0.500+/-0.265$ & $0.0007+/-0.0004$ & 0.500 \\
& East Whale Bay & 8 & 710 & 8 & 12 & $1.00+/-0.0039$ & $0.0062+/-0.0010$ & 4.429 \\
& BAMZ & 8 & 710 & 3 & 8 & $0.464+/-0.040$ & $0.0043+/-0.0018$ & 3.071 \\
\hline H. harringtonensis & ALL & 25 & 718 & 9 & 8 & $0.640+/-0.107$ & $0.00295+/-0.000002$ & 0.780 \\
& Whalebone Bay & 8 & 718 & 4 & 3 & $0.750+/-0.139$ & $0.0013+/-0.0016$ & 0.929 \\
& Frank's Bay & 7 & 718 & 2 & 1 & $0.286+/-0.196$ & $0.0006+/-0.0006$ & 0.286 \\
& Bailey's Bay & 2 & 718 & 1 & 0 & 0 & 0.00 & 0 \\
& BAMZ & 8 & 718 & 6 & 5 & $0.893+/-0.111$ & $0.0027+/-0.0016$ & 1.25 \\
\hline H. humeralis & ALL & 10 & 707 & 5 & 4 & $0.667+/-0.163$ & $0.0011+/-0.0004$ & 0.800 \\
& BAMZ & 6 & 707 & 4 & 3 & $0.800+/-0.172$ & $0.0014+/-0.0004$ & 1.000 \\
& Coney Island & 4 & 707 & 2 & 1 & $0.500+/-0.265$ & $0.0007+/-0.0004$ & 0.500 \\
\hline J. lamprotaenia & ALL & 27 & 718 & 10 & 9 & $0.650+/-0.103$ & $0.0013+/-0.0003$ & 0.934 \\
& South Bay & 8 & 718 & 3 & 3 & $0.607+/-0.164$ & $0.0013+/-0.0005$ & 0.929 \\
& Coney Island & 9 & 718 & 5 & 4 & $0.722+/-0.159$ & $0.0015+/-0.0005$ & 1.056 \\
& Frank's Bay & 1 & 718 & 1 & 0 & 0 & 0 & 0 \\
\hline S. aurita oglinum & Turtle Bay & 1 & 718 & 1 & 0 & 0 & 0 & 0 \\
& BAMZ & 8 & 718 & 5 & 4 & $0.786+/-0.151$ & $0.0014+/-0.0004$ & 1.000 \\
\hline & ALL & 8 & 709 & 2 & 1 & $0.429+/-0.169$ & $0.0006+/-0.0002$ & 0.429 \\
& Deep Bay & 3 & 709 & 2 & 1 & $0.667+/-0.314$ & $0.0009+/-0.0004$ & 0.667 \\
& BAMZ & 5 & 709 & 2 & 1 & $0.400+/-0.237$ & $0.0006+/-0.0003$ & 0.400 \\
\hline & BAMZ & 2 & 681 & 2 & 3 & $1.000+/-0.500$ & $0.0044+/-0.0022$ & 3.000 \\
\hline
\end{tabular}

1 


\section{Table 2 (on next page)}

Genetic Connectivity within Bermuda.

Pairwise $F_{\text {ST }}$ values among sampling locations for each species. Significant comparisons are indicated in bold $(\alpha=0.05)$. 


\begin{tabular}{|c|c|c|c|c|c|}
\hline A. choerostoma & West Whale Bay & East Whale Bay & BAMZ & & \\
\hline West Whale Bay & 0 & & & & \\
\hline East Whale Bay & 0.07556 & 0 & & & \\
\hline BAMZ & 0.01604 & -0.05263 & 0 & & \\
\hline H. harringtonensis & Whalebone Bay & Frank's Bay & Bailey's Bay & BAMZ & \\
\hline Whalebone Bay & 0 & & & & \\
\hline Frank's Bay & 0.04465 & 0 & & & \\
\hline Bailey's Bay & -0.24551 & -0.3125 & 0 & & \\
\hline BAMZ & -0.02521 & -0.01165 & -0.31765 & 0 & \\
\hline H. humeralis & Coney Island & BAMZ & & & \\
\hline Coney Island & 0 & & & & \\
\hline BAMZ & -0.0297 & 0 & & & \\
\hline J. lamprotaenia & South Bay & Coney Island & Frank's Bay & Turtle Bay & BAMZ \\
\hline South Bay & 0 & & & & \\
\hline Coney Island & 0.00697 & 0 & & & \\
\hline Frank's Bay & -0.85714 & -0.9 & 0 & & \\
\hline Turtle Bay & -0.85714 & -0.9 & 0 & 0 & \\
\hline BAMZ & 0.00461 & 0.02589 & -1 & -1 & 0 \\
\hline O. oglinum & Deep Bay Beach & BAMZ & & & \\
\hline Deep Bay & 0 & & & & \\
\hline BAMZ & -0.29921 & 0 & & & \\
\hline
\end{tabular}

1 


\section{Table 3 (on next page)}

AMOVA within Bermuda.

Analysis of molecular variance within and among sampled locations around Bermuda (Arlequin 3.5.2). Samples from all locations for a given species were considered as a single group. Significant $F_{\mathrm{ST}}$ indices are indicated in bold $(\alpha=0.05)$. 


\begin{tabular}{|c|c|c|c|c|c|c|}
\hline Species & Source of Variation & d.f. & $\begin{array}{l}\text { Sum of } \\
\text { Squares }\end{array}$ & $\begin{array}{c}\text { Variance } \\
\text { components }\end{array}$ & $\begin{array}{l}\text { Percentage of } \\
\text { total variation }\end{array}$ & $\begin{array}{l}\text { Fixation } \\
\text { indices }\end{array}$ \\
\hline \multicolumn{7}{|c|}{ A. choerostoma } \\
\hline & Among locations & 2 & 3.05 & $-0.00988 \mathrm{Va}$ & -0.63 & \multirow[t]{3}{*}{$F_{\mathrm{ST}}:-0.00626$} \\
\hline & Within locations & 17 & 27.00 & $1.58824 \mathrm{Vb}$ & 100.63 & \\
\hline & Total & 19 & 30.05 & 1.57835 & & \\
\hline \multicolumn{7}{|c|}{ H. harringtonensis } \\
\hline & Among locations & 3 & 0.88 & $-0.01880 \mathrm{Va}$ & -4.88 & \multirow[t]{3}{*}{$F_{\mathrm{ST}}:-0.04882$} \\
\hline & Within locations & 21 & 8.48 & $0.40391 \mathrm{Vb}$ & 104.88 & \\
\hline & Total & 24 & 9.36 & 0.38511 & & \\
\hline \multicolumn{7}{|c|}{ H. humeralis } \\
\hline & Among locations & 1 & 0.35 & $-0.01172 \mathrm{Va}$ & -2.97 & \multirow[t]{3}{*}{$F_{\mathrm{ST}}:-0.02970$} \\
\hline & Within loclations & 8 & 3.25 & $0.40625 \mathrm{Vb}$ & 102.97 & \\
\hline & Total & 9 & 3.60 & 0.39453 & & \\
\hline \multicolumn{7}{|c|}{ J. lamprotaenia } \\
\hline & Among locations & 4 & 1.18 & $-0.04269 \mathrm{Va}$ & -9.36 & \multirow[t]{3}{*}{$F_{\mathrm{ST}}:-0.09361$} \\
\hline & Within locations & 22 & 10.97 & $0.49874 \mathrm{Vb}$ & 109.36 & \\
\hline & Total & 16 & 12.15 & 0.45605 & & \\
\hline \multicolumn{7}{|c|}{ O. oglinum } \\
\hline & Among locations & 1 & 0.03 & $-0.05630 \mathrm{Va}$ & -29.92 & \multirow[t]{3}{*}{$F_{\mathrm{ST}}:-0.29921$} \\
\hline & Within locations & 6 & 1.47 & $0.24444 \mathrm{Vb}$ & 129.92 & \\
\hline & Total & 7 & 1.50 & 0.18815 & & \\
\hline
\end{tabular}


Table 4 (on next page)

Regional Genetic Connectivity.

Pairwise $F_{\mathrm{ST}}$ values among regions for each species. Significant comparisons are indicated in bold $(\alpha=0.05)$. 


\begin{tabular}{lcccc}
\hline A. choerostoma & $\mathrm{n}$ & Bermuda & Florida & \\
\hline Bermuda & 20 & 0 & & \\
Florida & 5 & $\mathbf{0 . 4 6 2 1 1}$ & $\mathbf{0}$ & \\
(A. lamprotaenia) & & & & \\
\hline H. harringtonensis & $\mathrm{n}$ & Bermuda & Belize & \\
\hline Bermuda & 25 & 0 & & \\
Belize & 2 & $\mathbf{0 . 9 7 0 5 3}$ & $\mathbf{0}$ & \\
\hline H. humeralis & $\mathrm{n}$ & Bermuda & Mexico & \\
\hline Bermuda & 10 & 0 & & \\
Mexico & 4 & 0.08142 & 0 & \\
Belize & 2 & -0.32353 & -0.26316 & 0 \\
\hline J. lamprotaenia & $\mathrm{n}$ & Bermuda & Mexico & Belize \\
\hline Bermuda & 27 & 0 & & \\
Mexico & 17 & $\mathbf{0 . 9 8 3 8 9}$ & 0 & \\
Belize & 5 & $\mathbf{0 . 9 2 3 8 1}$ & $\mathbf{0 . 9 2 3 8 1}$ & 0 \\
\hline O. oglinum & $\mathrm{n}$ & Bermuda & Mexico & Brazil \\
\hline Bermuda & 8 & 0 & & \\
Mexico & 4 & $\mathbf{0 . 5 6 4 0 8}$ & 0 & 0 \\
Brazil & 6 & $\mathbf{0 . 6 9 1 0 0}$ & 0.15109 & 0 \\
\hline S. aurita & $\mathrm{n}$ & Bermuda & Turkey & Israel \\
\hline Bermuda & 2 & 0 & & \\
Turkey & 3 & $\mathbf{0 . 6 8 9 0 2}$ & 0 & \\
Israel & 6 & $\mathbf{0 . 8 0 8 4 0}$ & -0.05882 & 0 \\
\hline
\end{tabular}

1 


\section{Table 5 (on next page)}

\section{AMOVA Among Regions.}

Analysis of molecular variance among and within regions (Arlequin 3.5.2). Populations from all regions for a given species were considered as a single group. Significant $F_{\mathrm{ST}}$ indices are indicated in bold $(\alpha=0.05)$. 


\begin{tabular}{|c|c|c|c|c|c|c|}
\hline Species & Source of Variation & d.f. & $\begin{array}{l}\text { Sum of } \\
\text { Squares }\end{array}$ & $\begin{array}{c}\text { Variance } \\
\text { components }\end{array}$ & $\begin{array}{l}\text { Percentage of } \\
\text { total variation }\end{array}$ & $\begin{array}{l}\text { Fixation } \\
\text { indices }\end{array}$ \\
\hline \multicolumn{7}{|c|}{$\begin{array}{l}\text { A. choerostoma / } \\
\text { lamprotaenia }\end{array}$} \\
\hline & Among regions & 1 & 9.67 & $1.05522 \mathrm{Va}$ & 46.21 & \multirow[t]{3}{*}{$F_{\mathrm{ST}}: 0.46211$} \\
\hline & Within regions & 23 & 28.25 & $1.22826 \mathrm{Vb}$ & 53.79 & \\
\hline & Total & 14 & 37.92 & 2.28348 & & \\
\hline \multicolumn{7}{|c|}{ H. harringtonensis } \\
\hline & Among regions & 1 & 46.05 & $12.33171 \mathrm{Va}$ & 97.05 & \multirow{3}{*}{$F_{\mathrm{ST}}: 0.97053$} \\
\hline & Within regions & 25 & 9.36 & $0.37440 \mathrm{Vb}$ & 2.95 & \\
\hline & Total & 26 & 55.41 & 12.70611 & & \\
\hline \multicolumn{7}{|c|}{ H. humeralis } \\
\hline & Among regions & 2 & 0.90 & $-0.01357 \mathrm{Va}$ & -2.75 & \multirow[t]{3}{*}{$F_{\mathrm{ST}}:-0.02747$} \\
\hline & Within regions & 13 & 6.60 & $0.50769 \mathrm{Vb}$ & 102.75 & \\
\hline & Total & 15 & 7.50 & 0.49412 & & \\
\hline \multicolumn{7}{|c|}{ J. lamprotaenia } \\
\hline & Among regions & 2 & 1061.95 & $38.14984 \mathrm{Va}$ & 94.25 & \multirow[t]{3}{*}{$F_{\mathrm{ST}}: 0.94252$} \\
\hline & Within regions & 46 & 107.03 & $2.32675 \mathrm{Vb}$ & 5.75 & \\
\hline & Total & 48 & 1168.98 & 40.47659 & & \\
\hline \multicolumn{7}{|c|}{ O. oglinum } \\
\hline & Among regions & 2 & 14.53 & $1.09471 \mathrm{Va}$ & 53.83 & \multirow[t]{3}{*}{$F_{\mathrm{ST}}: 0.53831$} \\
\hline & Within regions & 15 & 14.08 & $0.93889 \mathrm{Vb}$ & 46.17 & \\
\hline & Total & 17 & 28.61 & 2.0336 & & \\
\hline \multicolumn{7}{|l|}{ S. aurita } \\
\hline & Among regions & 2 & 8.23 & $1.08507 \mathrm{Va}$ & 65.86 & \multirow[t]{3}{*}{$F_{\mathrm{ST}}: 0.65859$} \\
\hline & Within regions & 8 & 4.50 & $0.56250 \mathrm{Vb}$ & 34.14 & \\
\hline & Total & 10 & 12.73 & 1.64757 & & \\
\hline
\end{tabular}




\section{Figure 1}

Map of Bermuda.

Map indicating the locations of bays that are currently closed to net fishing (red circles with strikethrough) and of sampled baitfish populations (pie charts). Size of pie charts represents the total number of individuals sequenced from that location. Colors within the circles represent the relative abundance of each species found at each location. The inset shows the isolated location of Bermuda within the west central Atlantic. 


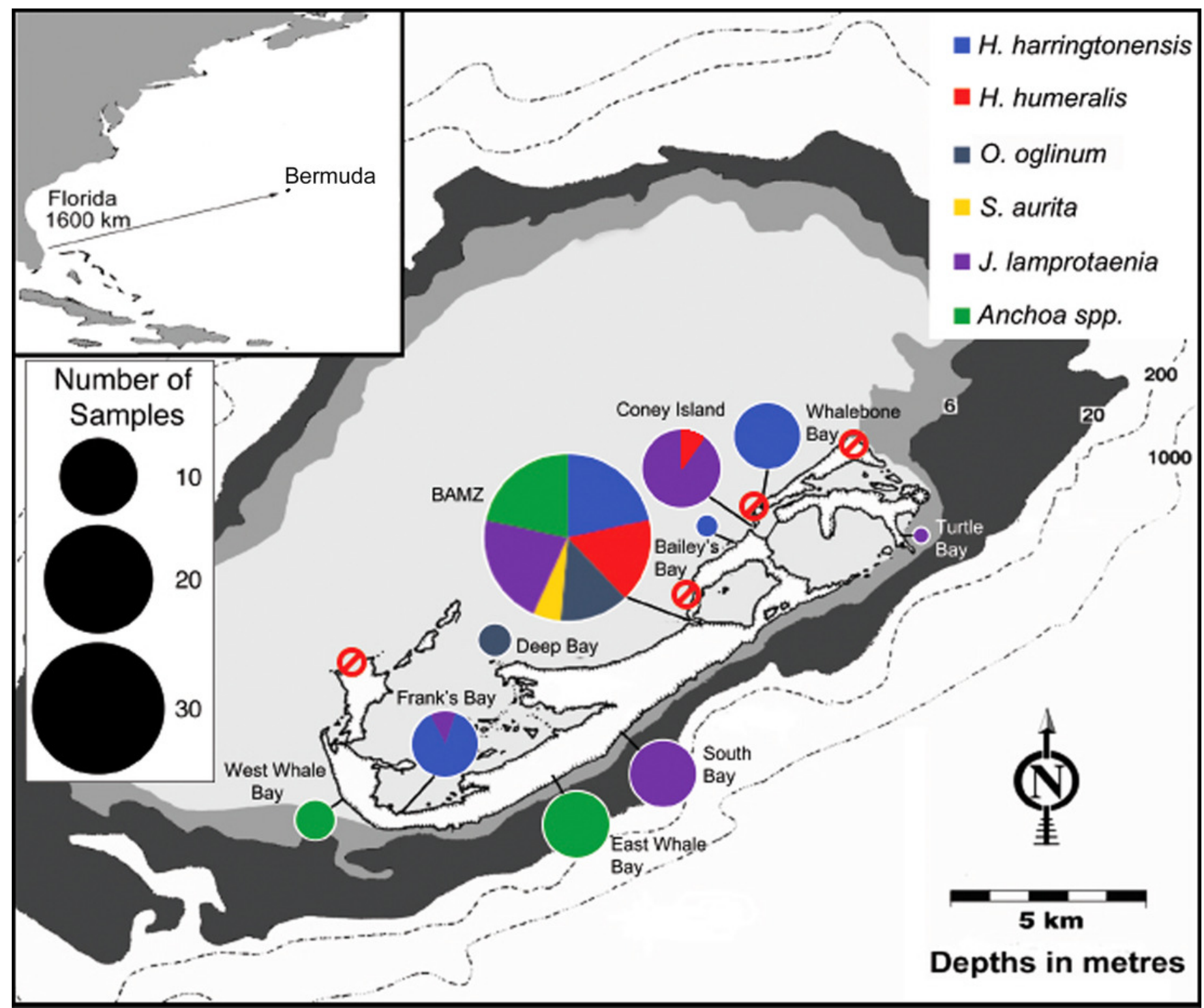




\section{Figure 2}

Molecular Phylogenetic Analysis.

The evolutionary history was inferred from a single gene tree using the Maximum Likelihood method based on the Tamura-Nei model. The tree with the highest log likelihood (-4350.82) is shown. The percentage of trees in which the associated taxa clustered together is shown next to the branches. Initial trees for the heuristic search were obtained automatically by applying Neighbor-Join and BioNJ algorithms to a matrix of pairwise distances estimated using the Maximum Composite Likelihood (MCL) approach, and then selecting the topology with superior log likelihood value. The tree is drawn to scale, with branch lengths in the number of substitutions per site. The analysis involved 154 nucleotide sequences. There were a total of 718 positions in the final dataset. Evolutionary analyses were conducted in MEGA X. 


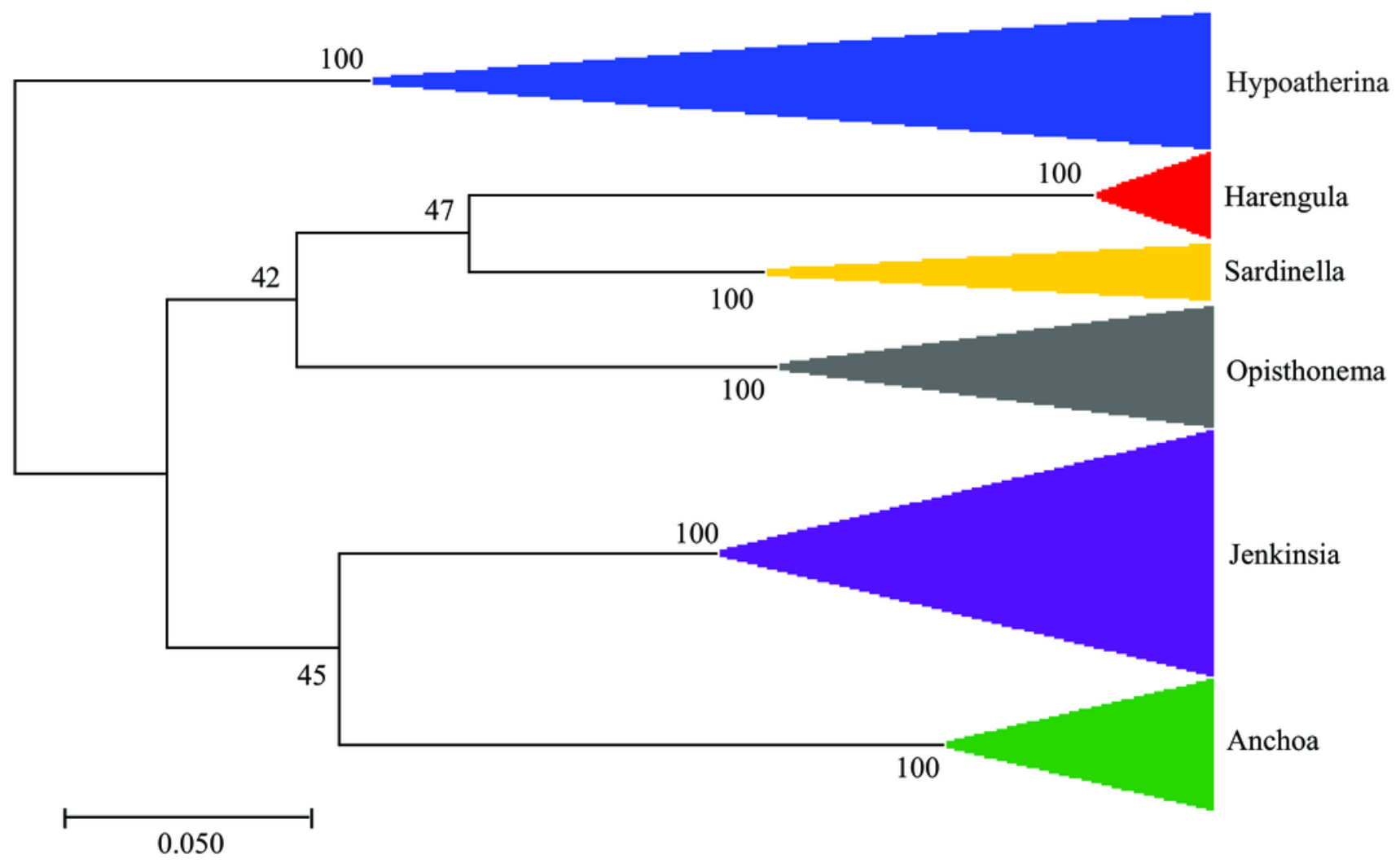

